\title{
Cuts coming on overheads
}

\section{Washington}

A CAP on the indirect costs of research, only a rumour two weeks ago, now seems nearly certain as US government officials and congressional leaders rush to respond to the overcharging scandal that is striking a growing number of US universities.

At a series of congressional hearings last week, Bush Administration officials launched a preemptive strike against feared congressional initiatives by proposing their own across-the-board caps on indirect costs. A task force on the subject chaired by Bernardine Healy, the new director of the National Institutes of Health (NIH), is seriously considering limits on total costs as well as restrictions on the portion of those costs that cover administrative expenses.

Richard Kusserow, inspector general of the Department of Health and Human Service (HHS) and a member of Healy's task force, testified that capping indirect costs at 50 per cent of direct research costs would save some $\$ 125$ million each year, which could fund about 1,000 new research grants at NIH. Although 50 per cent is about the current average for indirect costs, declaring it an absolute ceiling would force universities above the average to lower their rates, resulting in an overall reduction in cost to the federal government - a reduction that universities will have to make up from their own resources.

Other proposals also remain under active consideration by the Healy panel and the White House Office of Management and Budget, although they are seen as less likely than the option of capping indirect costs. These alternatives include 'block grants' to universities, in which researchers and administrators would decide between themselves how much should go to direct and indirect costs, as well as grants awarded directly to researchers, who would then negotiate with their administrators what proportion would go to indirect costs.

Five years ago, the federal government proposed and nearly succeeded in winning a cap on the administrative portion of indirect costs, following the recommendations of a report by D. Allan Bromley (now director of the White House Office of Science and Technology Policy) and industrialist David Packard. At the time, such a cap would have saved $\$ 85$ million per year - perhaps half of what a similar measure might save today in the larger NIH budget.

Last week, that proposal was resurrected when Kevin Moley of HHS suggested at least a 26 per cent cap on administrative indirect costs, which currently make up about half of total indirect costs. Given the accounting reforms since 1986, a ceiling on administrative costs might even be profitably lowered further, Moley told a congressional committee. HHS is also said to be considering a 20 per cent level.
Although that sort of proposal had full federal support in 1986, Congress, under university pressure, put language in its appropriations bill to prohibit it. This time, however, in the midst of an indirect-cost scandal, Congress seems unlikely to offer much opposition. Indeed, there is an unmistakable groundswell of determined - if somewhat undirected - congressional enthusiasm for cost cuts.

Science supporters fear that congressional appropriations committees, faced with deficit troubles and a host of competing financial demands, may simply reduce the NIH budget in anticipation of the savings from whatever cost-control plan is finally adopted. That money would presumably go to fill needs elsewhere in the US budget.

Science supporters in Congress are anxious to convince colleagues of the dangers of hasty cuts. "Most members of Congress", says George Brown (Democrat, California), chairman of the House Science Committee and strong research supporter, “don't understand the issue and don't understand why the money [saved by capping indirect costs] should go back into science. As the possibility of a cap dawns, some of us will be trying to educate them."

Meanwhile, university administrators, fearing that the issue will soon be out of their hands, are trying to be seen as responsible. The Association of American Universities last week told congressional leaders that it has asked a panel of university presidents to visit Washington and meet federal officials "to correct errors which call into question our commitment to contain and monitor prudently and responsibly the costs of conducting sponsored research."

Christopher Anderson ANIMAL RESEARCH

\section{Court puts rules in question}

\section{Washington}

A US COURT victory earlier this month by an animal-welfare organization has opened the door to a legal battle over federal restrictions on the care of rats, mice and birds in research, as well as a possible attack on the rules covering primates, dogs and cats.

The suit, filed in June last year by the Animal Legal Defense Fund, sought to force the US Department of Agriculture (USDA) to include rats, mice and birds in its animal care and housing regulations, which govern all US laboratory animals.

A clause in the 1971 congressional act that compels USDA to protect the welfare of laboratory animals gives the administrator of the agency the authority to determine what is and is not to be defined as a research animal. To simplify its enforcement, USDA has chosen not to define rats, mice and birds as 'animals' for regulatory purposes. The agency argues that including them would greatly increase its administrative workload without greatly improving their welfare, as most laboratory rat and mouse enclosures are already constructed in compliance with the accepted guidelines of the National In-

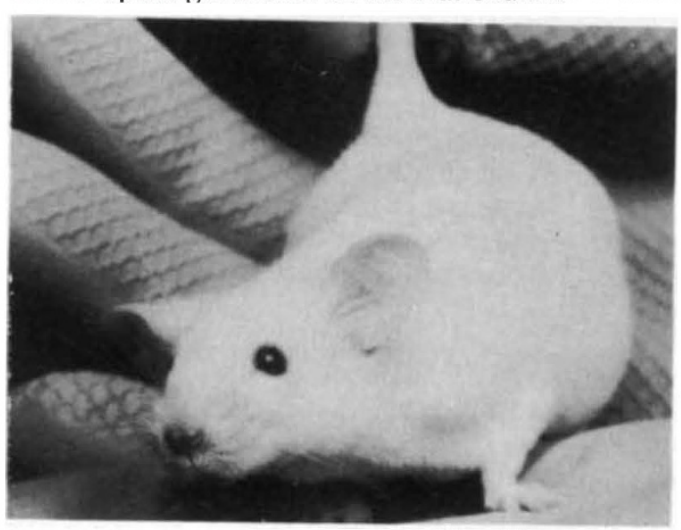

Is this laboratory mouse an animal? USDA says no. stitutes of Health.

In its decision earlier this month, the US District Court for the District of Columbia ruled that the animal defence group has the right to sue because it had been prevented from distributing information on laboratory rats, mice and birds by the USDA decision. Because USDA does not collect information on the animals and report it to Congress, the group is unable to pass the information on to its members, and is prevented from carrying out one of its primary functions, the court decided.

Known as 'informational standing', the ruling appears to open the door to other lawsuits by animal-welfare organizations. Many previous legal challenges by activists failed when the organizations were unable to prove to the court's satisfaction that they had been materially damaged by government action, an essential requirement for legal standing.

Other animal organizations, including the Animal Welfare Institute, are closely watching the suit, with an eye on the newly released USDA regulations on primates, dogs and cats (see Nature 349, 641; 21 February 1991). Activists believe that the new rules, which give laboratories great flexibility in determining the details of enclosures and exercise regimes, are in violation of congressional intent. Now, they are considering suing.

The district court will turn its attention next to the merits of the animal defence fund's case. If it wins outright, USDA could be forced to include rats, mice and birds in its regulations. That would more than double the number of facilities the agency must inspect, and could cost several million dollars each year in additional regulatory expenses, according to USDA calculations. Christopher Anderson

NATURE · VOL $350 \cdot 25$ APRIL 1991 